\title{
TINGKAT KESANTUNAN BERBAHASA ADUAN DAN ASPIRASI DALAM LAPOR UNIT LAYANAN TERPADU UPI: KAJIAN PRAGMATIK
}

\author{
Undang Sudana ${ }^{1,}$ Jatmika Nurhadi $^{2,}$ Rahmawati $^{3,}$ Karina Diah Rahmawati ${ }^{4}$, Reza \\ Tarmudi Firdaus ${ }^{5}$ \\ ${ }^{1}$ Universitas Pendidikan Indonesia: undangsudana@upi.edu \\ ${ }^{2}$ Universitas Pendidikan Indonesia: jatmikanurhadi@upi.edu \\ ${ }^{3}$ Universitas Pendidikan Indonesia: rahma1a@upi.edu \\ ${ }^{4}$ Universitas Pendidikan Indonesia: karinadiahr17@upi.edu \\ ${ }^{5}$ Universitas Pendidikan Indonesia: rezatarmudi20@upi.edu
}

Artikel Info

Received : 12 Juli 2021

Accepted : 30 Okt 2021

Published : 29 Nov 2021
Abstrak

This study aims to identify the level of politeness in the language of complaints and aspirations contained in the UPI LAPOR. To support the research objectives, this research uses a qualitative descriptive approach with the help of pragmatic analysis. This study utilizes corpus data in the form of complaints and aspirations, totaling 47 texts in the UPI LAPOR for the period January 2019 to December 2020 as research data. The results showed that complaints and aspirations included in the very polite category were 15 data $(32 \%)$, polite category was 17 data $(36 \%)$, impolite category was 11 data (23\%), and very disrespectful category was 4 data (9\%). The percentage indicates that the party giving the complaint and aspiration conveys it in a polite manner. This is because the intended parties in complaints and aspirations have different social statuses, so they are encouraged to submit complaints and aspirations in a polite manner.

Keywords: complaint, aspiration, language politeness, UPI's LAPOR, pragmatic

\section{A. PENDAhuluan}

Dilansir dari portal berita Universitas Pendidikan Indonesia (UPI), UPI meraih peringkat 1 Program Layanan Aspirasi dan Pengaduan Online Rakyat (LAPOR) dari Kementerian Pendidikan dan Kebudayaan (Kemdikbud) RI. Itu menandakan UPI sudah berhasil dalam memfasilitasi masyarakat di lingkungan UPI untuk menyampaikan aduan dan aspirasinya. LAPOR UPI merupakan sebuah sarana bagi mahasiswa untuk berkomunikasi menyampaikan aduan dan aspirasinya kepada pemangku jabatan di UPI. LAPOR UPI sebagai sarana untuk menampung aduan dan aspirasi mahasiswa UPI bersifat komunikasi satu arah dan termasuk ke dalam umpan balik tertunda (delayed feedback) atau tidak langsung (indirect feedback), sehingga respons pihakpihak yang dituju dalam aduan dan aspirasi mahasiswa UPI tidak bisa langsung diketahui oleh pembuat aduan dan aspirasi 
(Soyomukti, 2012, p. 193). Sperber dan Wilson (1995, p. 172) menyebutkan bahwa bahasa dan komunikasi dianggap sebagai dua sisi mata uang. Dalam pandangan ini, ciri esensial bahasa adalah digunakan dalam komunikasi dan ciri esensial komunikasi adalah melibatkan penggunaan bahasa atau kode.

Sejauh ini, belum ada kajian khusus terhadap informasi aduan dan aspirasi yang ada di LAPOR UPI. Informasi aduan dan aspirasi hanya disampaikan kepada unit-unit tertentu dalam bentuk arsip. Oleh karena itu, informasi aduan dan aspirasi dalam Lapor UPI akan dilakukan analisis menggunakan pragmatik.

Pragmatik merupakan studi tentang penggunaan bahasa (Levinson, 1983; Verschueren, 1999, p. 1). Penelitian ini akan berfokus pada tingkat kesantunan berbahasa aduan dan aspirasi dalam Lapor UPI. Thomas (1995, p. 157) menyebutkan bahwa kesantunan dipandang sebagai sebuah fenomena pragmatik. Hal itu dikarenakan, topik utama pragmatik adalah aspek makna yang bergantung pada konteks (Birner, 2013, p. 2; Cruse, 2006, p. 3; Thomas, 1995, pp. 1-2). Bagian terpenting dari penggunaan bahasa dalam kajian pragmatik adalah untuk mengetahui apakah penutur sedang menginformasikan, mengkritik, menyalahkan, memperingatkan, memberi selamat, dan sebagainya (Cruse, 2006, p. 3). Praktik kesantunan berbahasa merupakan salah satu topik dalam kajian pragmatik yang melekat penggunaannya di masyarakat. Pragmatik berkaitan dengan jenis makna yang tidak ditemukan dalam kamus dan yang mungkin berbeda dari konteks ke konteks. Ucapan yang sama akan berarti hal yang berbeda dalam konteks yang berbeda, bahkan akan berarti hal yang berbeda bagi orang yang berbeda.

Bahasa memiliki banyak tujuan, salah satunya untuk mengungkapkan kesantunan linguistik (Holmes, 2009, p. 711). Kesantunan merupakan fondasi interaksi sosial yang didefinisikan secara luas sebagai seperangkat praktik yang digunakan untuk menghindari perselisihan atau pelanggaran komunikasi dan mempertahankan kerukunan komunikatif (Leech, 2007). Kesantunan dapat dilihat sebagai bagian utama dari strategi komunikasi sosial untuk membangun dan memelihara hubungan baik antaranggota masyarakat. Kesantunan linguistik dengan demikian merupakan masalah interaksi strategis yang bertujuan untuk mencapai tujuan, seperti menghindari konflik dan menjaga hubungan yang harmonis dengan orang lain (Kasper, 1990). Akan tetapi, kesantunan bukanlah sebuah kewajiban. Hal tersebut sejalan dengan pendapat dari Leech (2014, p. 4) yang menyebutkan bahwa salah satu dari delapan karakteristik kesantunan adalah kesantunan tidaklah wajib.

Penelitian terkait kesantunan berbahasa sudah banyak diteliti oleh peneliti terdahulu. Pertama, penelitian dari Yati dan Suprapti (2016), hasil penelitiannya menyebutkan bahwa kesantunan berbahasa mahasiswa jurusan kimia kepada dosen terdapat 36 maksim kebijaksanaan, 21 maksim kedermawanan, 28 maksim kesepakatan, 4 maksim pujian, dan 7 maksim simpati. Namun, terdapat 2 pernyataan yang tidak santun. Percakapan antara mahasiswa jurusan kimia 2012 dan dosen tergolong sangat santun dengan persentase penyimpangan maksim 2,08\% karena mahasiswa mematuhi maksim-maksim kesantunan. Pada data penelitian ditemukan mahasiswa masih menggunakan penyingkatan kata, penggunaan kata yang tidak baku, penggunaan simbol perasaan yang seolah kurang santun jika dikirimkan kepada dosen. Kedua, penelitian dari Zamzani, Musfiroh, Maslakhah, Listyorini, dan Yayuk (2011), hasil penelitiannya menunjukkan bahwa tindak tutur santun dapat diklasifikasikan berdasarkan topik dan fungsinya. Tindak tutur formal tatap muka dapat berupa 
kegiatan belajar mengajar, pertemuan formal, topik akademik lainnya, upacara adat, transaksi, negosiasi, dan pelayanan publik. Derajat dan karakteristik kesantunan disebabkan oleh berbagai faktor. Kedua penelitian ini tidak berfokus pada tingkat kesantunan berbahasa. Itulah yang membedakan penelitian terdahulu dengan penelitian ini. Penelitian ini mengurutkan data bahasa berupa aduan dan aspirasi dari kategori sangat santun sampai kategori sangat tidak santun.

Kesantunan merupakan masalah yang lebih umum untuk menunjukkan atau memberi kesan kepada orang lain. Kesantunan dapat dimanifestasikan melalui perilaku sosial, serta melalui sarana linguistik (Thomas, 1995, p. 150). Menurut Yule (1996, p. 59), interaksi linguistik merupakan interaksi sosial. Penerapan kesantunan berbahasa jauh lebih sederhana. Berdasarkan teori kesantunan, pengkodean linguistik bergantung pada sifat-sifat linguistik dan norma-norma penggunaan bahasa yang dikonvensionalkan (Kasper, 1990, p. 198).

Kesantunan dalam berbahasa sangat erat kaitannya dengan interaksi sosial di masyarakat. Leech (2014, p. 21) menyebutkan bahwa secara umum bentukbentuk kesantunan terjadi di masyarakat. Kesantunan berbahasa merupakan tatacara berperilaku yang disepakati oleh suatu masyarakat sebagai aturan perilaku sosial. Kesantunan pada dasarnya adalah masalah mempertimbangkan perasaan orang lain tentang bagaimana mereka harus diperlakukan secara interaksional, termasuk berperilaku dengan cara yang menunjukkan perhatian yang tepat untuk status sosial para pelaku interaksi dan hubungan sosial mereka (Brown, 2015). Dalam istilah semantik, "kesantunan" pada dasarnya adalah gagasan cara-adverbial. Praktik kesantunan tidak selalu berupa perilaku linguistik, tetapi biasanya demikian (Leech, 2014, p. 48).
Kesantunan adalah ciri penggunaan bahasa yang paling jelas untuk mengungkapkan sifat sosialitas manusia (Brown, 2015). Kesantunan pada dasarnya tidak berbeda dengan aspek lain dari makna suatu ujaran. Namun, kesantunan menjadi bagian dari makna eksplisit ujaran dan lebih sering diimplikasikan daripada diungkapkan secara terbuka. Kesantunan sangat penting untuk pembangunan dan pemeliharaan hubungan sosial, kesantunan dalam komunikasi menjadi inti kehidupan dan interaksi sosial; itu menjadi prasyarat untuk kerja sama manusia secara umum (Brown, 2015). Kesantunan berbahasa dapat berbentuk pujian atau ekspresi niat baik atau persahabatan, atau mungkin dalam bentuk permintaan yang dikurangi atau dilindungi, atau permintaan maaf karena melanggar batas waktu atau ruang seseorang (Holmes, 2009, p. 712).

Kesantunan adalah masalah normanorma sosial dan melekat dalam bentukbentuk linguistik tertentu ketika digunakan secara tepat sebagai penanda kategorikategori sosial yang telah diberikan sebelumnya (Brown, 2015). Brown kembali menyebutkan bahwa kesantunan secara konvensional melekat pada bentuk linguistik dan ekspresi formula tertentu, yang mungkin sangat berbeda dalam bahasa dan budaya yang berbeda. Selain itu, kesantunan berbahasa umumnya dianggap sebagai perhatian yang tepat dari 'pragmatik', bidang linguistik yang menjelaskan bagaimana kita mengaitkan makna dengan ucapan dalam konteks atau makna dalam interaksi (Thomas, 1995, p. 23).

Kesantunan dapat dicapai dalam situasi jarak atau kedekatan sosial. Kesantunan juga menggambarkan rasa hormat atau segan. Leech (2014, p. 14) menyebutkan bahwa sisi kesantunan yang berorientasi sosial dipelajari oleh sosiopragmatik dan mempelajari berbagai skala nilai yang membuat tingkat kesantunan tertentu tampak 
sesuai atau normal dalam lingkungan sosial tertentu.

Brown (2015) menyebutkan tiga kelompok utama pendekatan teoretis untuk analisis kesantunan dalam berbahasa, yaitu (1) kesantunan sebagai aturan sosial, (2) kesantunan sebagai ketaatan pada maksim kesantunan, dan (3) kesantunan sebagai manajemen wajah. Yule (1996, p. 60) juga menyebutkan bahwa kesantunan dalam suatu interaksi dapat didefinisikan sebagai sarana yang digunakan untuk menunjukkan kesadaran akan wajah orang lain.

Kesantunan berbahasa dapat diurutkan berdasarkan tingkat kesantunannya. Untuk mengetahui tingkat kesantunan bahasa, maka perlu dibuat tingkatan skala dan indikator yang menjadi penanda di setiap skalanya. Tingkat kesantunan berbahasa aduan dan aspirasi dalam penelitian ini menggunakan skala 1 sampai 4 dengan kategori sangat santun, santun, tidak santun, dan sangat tidak santun. Berikut adalah skala dan indikator dari setiap tingkat kesantunan berbahasa.

Pertama, skala 4 menunjukkan sangat santun dengan indikatornya, yaitu (1) diawali dan/atau diakhiri salam/ucapan selamat, (2) adanya penghargaan terhadap pihak yang dituju, (3) memperkenalkan diri, (4) aduan/aspirasi disampaikan dengan lugas, (5) permohonan disampaikan dengan cara santun, dan (6) diakhiri dengan ucapan 'terima kasih'. Kedua, skala 3 menunjukkan santun dengan indikatornya, yaitu (1) aduan/aspirasi disampaikan dengan lugas dan tegas, (2) aduan/aspirasi tidak menyudutkan/menyalahkan,

aduan/aspirasi tidak menggunakan diksi yang berkonotasi negatif, dan (4) menunjukkan rasa rendah hati. Ketiga, skala 2 menunjukkan tidak santun dengan indikatornya, yaitu (1) tidak adanya penghargaan terhadap pihak yang dituju, (2) aduan/aspirasi disampaikan dengan singkat,
(3) aduan/aspirasi
yang menyudutkan/menyalahkan,

dan aduan/aspirasi bersifat membandingkan pihak yang dituju dengan pihak lain. Keempat, skala 1 menunjukkan sangat tidak santun dengan indikatornya, yaitu (1) aduan/aspirasi menunjukkan rasa marah/kecewa/tidak suka, (2) aduan disampaikan dengan pertanyaan/pernyataan yang menyangsikan, (3) menggunakan diksi yang berkonotasi negatif, dan aduan/aspirasi bersifat menuntut.

\section{B. METODE}

Penelitian ini adalah penelitian deskriptif kualitatif yang bertujuan untuk mendeskripsikan secara kualitatif tingkat kesantunan berbahasa aduan dan aspirasi dalam LAPOR UPI. Adapun angka persentase yang terdapat dalam penelitian ini hanya digunakan untuk menunjang analisis. Data penelitian ini adalah 47 teks aduan dan aspirasi yang diperoleh dari LAPOR UPI periode Januari 2019 s.d. Desember 2020. Data yang telah diperoleh kemudian diklasifikasikan ke dalam 4 kategori berdasarkan skala dan indikator yang telah dibuat, yaitu kategori sangat santun, santun, tidak santun, dan sangat tidak santun. Adapun tahap-tahap dalam melakukan penelitian ini, yaitu 1) mengekstraksi data aduan dan aspirasi dari file database di ULT UPI; 2) menentukan tingkat kesantunan berbahasa ke dalam kategori sangat santun, santun, tidak santun, dan sangat tidak santun; 3) menentukan skala dan indikator di setiap kategori tingkat kesantunan berbahasa; 4) mengklasifikasikan 47 data aduan dan aspirasi berdasarkan tingkat kesantunan berbahasa; 5) menghitung persentase tingkat kesantunan berbahasa di setiap tingkatan; 6) menginterpretasi dan mendeskripsikan hasil pengklasifikasian; 7) menyimpulkan hasil interpretasi tingkat kesantunan berbahasa aduan dan aspirasi yang terdapat dalam LAPOR UPI. 


\section{HASIL DAN PEMBAHASAN Hasil}

Aduan dan aspirasi yang terdapat dalam LAPOR UPI memiliki tingkat kesantunan berbahasa yang berbeda-beda. Setelah 47 data aduan dan aspirasi diklasifikasikan ke dalam kategori sangat santun, santun, tidak santun, dan sangat tidak santun, maka selanjutnya adalah dihitung besaran persentase di setiap tingkatannya. Berikut adalah rumus yang digunakan untuk menghitung besaran persentase tingkat kesantunan berbahasa.

$$
\text { Persentase }=\frac{\text { Jumlah bagian }}{\text { Jumlah keseluruhan }}
$$

Jumlah bagian adalah jumlah aduan dan aspirasi yang termasuk ke dalam setiap kategori. Kemudian, jumlah keseluruhan adalah jumlah keseluruhan data aduan dan aspirasi yang berjumlah 47 data.

\section{Aduan dan Aspirasi Sangat Santun}

Aduan yang termasuk ke dalam kategori sangat santun harus memenuhi indikator yang sudah dibuat, yaitu (1) diawali dan/atau diakhiri salam/ucapan selamat, (2) adanya penghargaan terhadap pihak yang dituju, (3) memperkenalkan diri, (4) aduan/aspirasi disampaikan dengan lugas, (5) permohonan disampaikan dengan cara santun, dan (6) diakhiri dengan ucapan 'terima kasih'. Berikut adalah aduan yang termasuk kategori sangat santun. Berikut adalah aduan yang termasuk ke dalam kategori sangat santun.

\section{A (25)}

\section{Yth.}

Bapak/ ibu pimpinan pddikti

Assalamu'alaikum w. W.

Sebelum saya menyampaikan maksud saya, izinkan saya untuk memperkenalkan diri. Saya renita putri lestari, alumni ppg pasca sm-3t universitas pendidikan indonesia angkatan vi prodi pendidikan fisika.

Saya mewakili teman-teman ingin menyampaikan bahwa data mahasiswa dan no sertifikat pendidik kami belum terdata di pddikti. Kami sudah menghubungi pihak upi tentang hal ini. Jika pihak upi sudah menyampaikan ke pddikti, besar harapan kami agar pddikti dapat membantu kami terkait data tersebut untuk keperluan tes skb cpns 2019.

Di tengah mewabahnya covid-19 dan menyebabkan diundurnya skb, kami berharap dalam perpanjangan waktu ini data kami dapat terinput sebelum dilaksanakan seleksi tersebut. Semoga dalam kondisi yang terbatas ini, bapak/ibu berkenan membantu kami.

Kami berdoa semoga bapak/ibu senantiasa siberikan kesehatan. Akhir kata, atas perhatian bapak/ibu, kami mengucapkan terima kasih.

Wassalamu'alaikum w. W.

Aduan nomor 25 ini berisi tentang jadwal pencairan beasiswa PPA Dikti. Aduan di atas dikategorikan sebagai aduan yang sangat santun karena sudah memenuhi indikator sangat santun. Renita menempatkan dirinya sebagai mahasiswa, sehingga dirinya menghargai pihak yang dituju dalam aduan. Renita memberikan penghargaan dengan menggunakan diksi 'Yth.' kepada Bapak/Ibu Pimpinan PDDIKTI yang dianggap memiliki status yang lebih tinggi daripada dirinya. Selain itu, sebagai bentuk kesantunan, Renita mengawali aduannya dengan menuliskan salam dan memperkenalkan diri. Renita menyampaikan aduan dengan sangat halus dan permohonan yang disampaikanpun sangat sopan, serta diakhiri dengan ucapan terima kasih. Aduan dan aspirasi dalam LAPOR UPI yang termasuk ke dalam kategori sangat santun pun terdapat dalam aduan nomor 26. Perhatikan aduan nomor 26 di bawah ini. 
A (26)

Kepada yth.

1. Menteri pendidikan dan kebudayaan ri

2. Direktur jenderal pendidikan tinggi

3. Rektor universitas pendidikan indonesia

Assalamualaikum wr. Wb

Kami melaporkan selaku alumni pendidikan profesi guru (ppg) pasca sm$3 t$ angkatan vi universitas pendidikan indonesia tahun 2018 bahwa data kami semua selaku alumni ppg pasca sm-3t tahun 2018 belum terdata atau tercatat dalam sistem pddikti dan sivil.

Kami sangat kecewa perihal ini. Kami memohon kepada pihak universitas pendidikan indonesia untuk sesegera mungkin dan secepat mungkin untuk menginput data kami semua, agar kami tidak disebut alumni dengan sertifikat pendidik yang ilegal atau tidak sah karena data kami di pddikti dan sivil belum tercatat padahal kami sudah lulus dari tahun 2018 akan tetapi sampai tahun ini 2020 data kami di pddikti dan civil belum tercatat juga.

Demikian laporan dan keluhan kami alumni ppg pasca sm-3t upi angkatan vi tahun 2018.

Besar harapan kami pihak upi untuk menindaklanjuti laporan dan keluhan kami dengan cepat dan tepat. Terima kasih.

Aduan nomor 26 ini berisi tentang belum tercatatnya data alumni PPG Pasca SM-3T Tahun 2018 di PDDIKTI dan Civil. Seperti aduan nomor 25, aduan nomor 26 pun memberikan penghargaan terhadap pihak yang dituju dalam aduan. Penghargaan tersebut berupa penggunaan diksi 'yth.' kepada Menteri Pendidikan dan Kebudayaan RI, Dirjen Dikti, dan Rektor UPI. Alumni PPG UPI mengawali aduannya dengan menuliskan ucapan salam dan dilanjutkan dengan menyampaikan inti aduan secara lugas. Harapan dan permohonan pun disampaikan dengan cara yang santun dengan menggunakan redaksi 'besar harapan kami (...)'. Terakhir, aduan diakhiri dengan ucapan terima kasih. Itu semua merupakan wujud kesantunan Alumni PPG UPI dalam menyampaikan keluhannya. Hal itu dikarenakan, ada kesadaran dari Alumni PPG UPI untuk menghargai pihak yang dituju.

Dari 47 aduan dan aspirasi yang terdapat dalam LAPOR UPI ditemukan 15 aduan dan aspirasi yang memenuhi indikator sangat santun. Berikut adalah jumlah persentasenya.

$$
\text { Sangat santun }=\frac{15}{47} \times 100 \%=31,9 \%
$$

Dari 47 aduan dan aspirasi yang terdapat dalam LAPOR UPI, ditemukan 15 data $(31,9 \%)$ aduan dan aspirasi yang termasuk ke dalam kategori sangat santun. Aduan dan aspirasi sebesar 31,9\% merupakan angka yang cukup tinggi. Terlebih, 15 dari 47 data termasuk ke dalam kategori sangat santun. Hal itu menunjukkan bahwa pihak yang memberikan aduan dan aspirasi ke dalam LAPOR UPI menerapkan sikap sopan santun kepada pihak yang dituju.

\section{Aduan dan Aspirasi Santun}

Aduan yang termasuk ke dalam kategori santun harus memenuhi indikator yang sudah dibuat, yaitu (1) aduan/aspirasi disampaikan dengan tegas, (2) aduan/aspirasi tidak menyudutkan/menyalahkan, aduan/aspirasi tidak menggunakan diksi yang berkonotasi negatif, dan (4) menunjukkan rasa rendah hati. Berikut adalah aduan yang termasuk kategori santun. A (18)

Kepada civitas akademik upi..

saya sebagai alumni upi sangat membutuhkan akreditasi kampus baik yang terbaru maupun yang lama. alangkah baiknya pihak upi menyediakan file yang bisa di download 
Berdasarkan aduan atas, aduan nomor 18 berisi tentang permintaan alumni UPI mengenai akreditasi kampus terbaru. Aduan tersebut disampaikan dengan tegas dan tidak bertele-tele. Walaupun demikian, alumni UPI sebagai orang yang memberikan aduan tidak menyudutkan pihak yang dituju. Diksi yang digunakan pun tidak berkonotasi negatif. Alumni UPI justru menunjukkan rasa rendah hati dan menunjukkan sikap bahwa dirinya merasa 'butuh' akan akreditasi kampus yang terbaru. Sikap itu ditunjukkan melalui redaksi 'saya sebagai alumni upi sangat membutuhkan akreditasi kampus (...)'. Lebih dari itu, aduan nomor 18 pun berisi tentang aspirasi. Alumni UPI memberikan aspirasi terkait penyediaan file akreditasi yang dapat diunduh oleh pihakpihak yang membutuhkan. Aduan dan aspirasi dalam LAPOR UPI yang termasuk ke dalam kategori santun pun terdapat dalam aduan nomor 29. Perhatikan aduan nomor 29 di bawah ini.

\section{A (29)}

Saya ingin melaporkan bahwa pihak ptn upi purwakarta yg telah menerima mahasiswa jalur snmpt tidak memberi keringanan ukt dan juga perpanjangan waktu pembayaran ditengah masa sulit ini, walaupun sudah mengajukan keringanan. mengapa tidak ada keringanan dalam hal pembayaran ukt, sehingga mahasiswa yg tidak mampu membayar sampai tgl. 15 mei 2020 dianggap mengundurkan diri/gugur. waktu pembayaran hanya diberi keringanan perpanjangan 4 hari saja yang awalnya 11 mei menjadi 15 mei 2020. sedangkan dari kemendikbud sudah ada pernyatan untuk dapat memberi keringan bagi mahasiswa yg ekonominya terdampak covid 19 (terlampir).

mohon pihak lapor.go.id dapat menyampaikan permasalahan ini ke pihak terkait, yang saya juga bingung harus lapor kemana saja karna waktu yg sangat mendesak ini. karena saya merasa ini sangat penting untuk kelangsungan masa depan anak saya. atas perhatiannya saya ucapkan terimakasih.

Aduan nomor 29 berisi tentang kebijakan yang diberikan oleh Pimpinan Kampus Daerah Purwakarta UPI yang tidak memberikan keringanan pembayaran UKT mahasiswa jalur SNMPTN. Aduan tersebut disampaikan secara tegas tanpa bertele-tele. Aduan nomor 29 pun menunjukkan sikap 'butuh'. Hal itu terdapat pada bagian '(...) karna saya merasa ini sangat penting untuk kelangsungan masa depan anak saya.'. Aduan ini masih tergolong aduan santun, sebab diksi yang digunakan tidak berkonotasi negatif. Lalu, permintaan yang diajukan menggunakan kata 'mohon' dan diakhiri dengan ucapan terima kasih, sehingga menunjukkan adanya kesadaran akan menjaga sikap santun terhadap pihak yang dituju.

Dari 47 aduan dan aspirasi yang terdapat dalam LAPOR UPI ditemukan 17 aduan dan aspirasi yang memenuhi indikator santun. Berikut adalah jumlah persentasenya.

$$
\text { Santun }=\frac{17}{47} \times 100 \%=36,2 \%
$$

Berdasarkan hasil perhitungan persentase di atas, dapat diketahui bahwa ditemukan 17 data aduan dan aspirasi yang termasuk ke dalam kategori santun dengan persentase sebesar $36,2 \%$. Aduan dan aspirasi yang termasuk ke dalam kategori santun lebih besar daripada aduan dan aspirasi yang termasuk ke dalam kategori sangat santun. Hal ini menunjukkan bahwa aduan dan aspirasi yang disampaikan melalui LAPOR UPI masih dalam taraf santun dan diksi yang digunakan tidak kasar atau tidak berkonotasi negatif.

\section{Aduan dan Aspirasi Tidak Santun}


Aduan yang termasuk ke dalam kategori tidak santun harus memenuhi indikator yang sudah dibuat, yaitu (1) tidak adanya penghargaan terhadap pihak yang dituju, (2) aduan/aspirasi disampaikan dengan singkat, (3) aduan/aspirasi yang menyudutkan/menyalahkan, dan aduan/aspirasi bersifat membandingkan pihak yang dituju dengan pihak lain. Berikut adalah aduan yang termasuk ke dalam kategori tidak santun.

A (13)

Kenapa pembagian sertifikat pendidik di UPI terasa lambat???? padhal teman seangkatan kami yg lulus tahap 1 tahun 2019 di LPTK lain sertifikatnya sudah dibagikan.. bagi saya yg masih honorer, dan akan mendaftar CPNS adanya sertifikat pendidik akan sangat bermanfaat.. \#kemenristek.dikti \#pascasarjanaUPI

Aduan nomor 13 di atas menunjukkan bahwa aduan nomor 13 disampaikan dengan sangat singkat. Pihak yang memberikan aduan pun tidak memberikan penghargaan terhadap pihak yang dituju. Hal itu dibuktikan dengan diksi yang digunakan tergolong tidak santun, seperti 'lambat'. Kata 'lambat' memiliki konotasi yang negatif dan jika ditinjau dari makna leksikalnya, kata 'lambat' berarti perlahanlahan, tidak cepat, memerlukan waktu banyak, dan tidak tepat pada waktunya. Selain itu, aduan nomor 13 pun membandingkan pihak yang dituju dengan pihak lain. Hal itu mengindikasikan bahwa pihak yang memberikan aduan menyudutkan pihak UPI dengan cara membandingkannya dengan pihak lain yang dirasa lebih baik. Aduan dan aspirasi dalam LAPOR UPI yang termasuk ke dalam kategori tidak santun pun terdapat dalam aduan nomor 24. Perhatikan aduan nomor 24 di bawah ini.

\section{A (24)}

\section{Mohon untuk ditindaklanjuti dengan sangat serius,.}

Universitas indonesia (upi) lembang bandung dalam hal penerbitan sertifikat pendidik (serdik) sangat lambat,lulus bulan november 2019 tapi sampai sekarang serdiknya tidak ada kabar kapan akan diserahkan kepada peserta plpg/ppg yang lulus ujian,. Hal ini membuat resah para guru yang lulus ujian plpg/ppg, karena dari universitas/perguruan tinggi yang lain sudah diserahkan serdiknya,dan sudah bisa di sinkronkan dengan dapodik,.

Berdasarkan aduan nomor 24 di atas, dapat diketahui bahwa aduan nomor 24 memiliki kesamaan dengan aduan nomor 13. Persamaannya adalah aduan nomor 24 disampaikan dengan sangat singkat dan tidak memberikan penghargaan kepada pihak yang dituju. Aduan nomor 24 pun menggunakan diksi 'lambat' yang diawali dengan diksi 'sangat'. Lalu, aduan nomor 24 juga membandingkan antara UPI dengan perguruan tinggi lainnya yang ditambahkan dengan pernyataan bahwa pengadu merasa resah atas kinerja panitia PLPG/PPG UPI Bandung.

Dari 47 aduan dan aspirasi yang terdapat dalam LAPOR UPI ditemukan 17 aduan dan aspirasi yang memenuhi indikator tidak santun. Berikut adalah jumlah persentasenya.

$$
\text { Tidak santun }=\frac{11}{47} \times 100 \%=23,4 \%
$$

Berdasarkan hasil perhitungan di atas, dapat diketahui bahwa ditemukan 11 data aduan dan aspirasi yang termasuk ke dalam kategori tidak santun dengan persentase $23,4 \%$. Besaran persentase ini memang jauh lebih kecil daripada kategori sangat santun dan santun, tetapi tetap saja ini menunjukkan bahwa aduan dan aspirasi masih banyak disampaikan dengan cara yang tidak santun. Jika dibenturkan dengan indikator kategori tidak santun, besaran persentase $23,4 \%$ ini menunjukkan bahwa pihak yang 
memberikan aduan dan aspirasi tidak memberikan penghargaan terhadap pihak yang dituju, aduan dan aspirasi pun bersifat menyudutkan dan menyalahkan. Selain itu, aduan dan aspirasi yang disampaikan pun membandingkan pihak yang dituju dengan pihak lain.

\section{Aduan dan Aspirasi Sangat Tidak Santun}

Aduan yang termasuk ke dalam kategori tidak santun harus memenuhi indikator yang sudah dibuat, yaitu (1) aduan/aspirasi menunjukkan rasa marah/kecewa/tidak suka, (2) aduan disampaikan dengan pertanyaan/pernyataan yang menyangsikan, (3) menggunakan diksi yang berkonotasi negatif, dan (4) aduan/aspirasi bersifat menuntut. Berikut adalah aduan yang termasuk ke dalam kategori sangat tidak santun.

A (22)

"JADWAL PEMBAYARAN UKT DI
UNIVERSITAS
INDONESIA NYELENEH!!!

saya sebagai orangtua mahasiswa merasa keberatan dan bertanya-tanya mengapa jadwal pembayaran UKT (semester genap 2019/2020) di UPI berbarengan dengan pelaksanaan UAS mahasiswa ??? Dimana pada umumnya, pembayaran UKT itu dilaksanakan setelah nilai UAS mahasiswa keluar. sungguh aneh. Mohon tindaklanjutnya."

Berdasarkan aduan nomor 22 di atas, aduan nomor 22 sangat jelas menunjukkan perasaan marah dan keberatan atas kebijakan UKT yang ditetapkan oleh UPI Bandung. Hal itu ditandai melalui 'saya sebagai orangtua mahasiswa merasa keberatan dan bertanya-tanya (...)'. Dari kutipan tersebut, dapat dilihat bahwa orang tua yang memberikan aduan terkait kebijakan UKT menunjukkan sikap bahwa dirinya merasa marah, keberatan, dan bingung atas waktu pembayaran UKT yang ditetapkan oleh UPI Bandung. Pengadu menyoroti waktu pembayaran UKT yang berbarengan dengan jadwal UAS, sebelum nilai mahasiswa keluar. Selain itu, aduan nomor 22 pun disampaikan dengan pertanyaan yang menyangsikan, seperti yang tertera pada bagian '(...) mengapa jadwal pembayaran UKT (semester genap 2019/2020) di UPI berbarengan dengan pelaksanaan UAS mahasiswa ??? Dimana pada umumnya, pembayaran UKT itu dilaksanakan setelah nilai UAS mahasiswa keluar.. sungguh aneh.' Dari kutipan tersebut, dapat diketahui bahwa pertanyaan tersebut menyangsikan kebijakan waktu pembayaran UKT di UPI Bandung. Lebih lanjut, pengadu menggunakan diksi yang memiliki konotasi negatif jika dilihat konteks aduan yang ada. Diksi yang berkonotasi negatif adalah 'nyeleneh' dan 'sungguh aneh'. Kata 'nyeleneh' memiliki arti tidak biasa dan aneh. Sementara itu, kata 'aneh' berarti berbeda dengan yang biasa dilihat, didengar, dan sebagainya. Dari diksi yang digunakan dan redaksi yang dibangun, aduan nomor 22 terkesan menuntut pihak UPI Bandung untuk menindaklanjuti hal ini.

Aduan dan aspirasi dalam LAPOR UPI yang termasuk ke dalam kategori sangat tidak santun pun terdapat dalam aduan nomor 40. Perhatikan aduan nomor 40 di bawah ini.

\section{A (40)}

saya mengikuti beasiswa bawaku, saya terus menanyakan informasi mengenai pencairan dana beasiswa. tetapi hingga h-1 terakhir pembayaran ukt masih blm ada kejelasan dr pihak UPI, sudah menanyakan ke pihak terkait yg mengurus beasiswa di direktorat kemahasiswaan jg blm dapat informasi dari pihak keuangan upi. jangan menganggap enteng masalah keuangan, saya sangat butuh uang beasiswa tersebut. tidak bisa lgsg menyiapkan uangnya hanya dalam waktu lhari. TOLONG KEJELASANNYA.

Terimakasih 
Berdasarkan aduan nomor 40 di atas, dapat dilihat bahwa mahasiswa yang mengirimkan aduan menunjukkan rasa kecewa dan marah dalam aduannya. Hal itu dapat dilihat melalui 'jangan menganggap enteng masalah keuangan, (...) TOLONG KEJELASANNYA.' Dari kutipan tersebut, mahasiswa menunjukkan rasa kekecewaan dan marah terkait waktu pencairan beasiswa yang cukup lama. Mahasiswa meminta pihak UPI untuk segera memberikan kejelasan dan tidak menganggap masalah uang sebagai masalah yang ringan. Kutipan itu pun menunjukkan bahwa mahasiswa menyangsikan sikap UPI Bandung terhadap beasiswa Bawaku. Mahasiswa menganggap pihak UPI Bandung menganggap permasalahan ini sebagai masalah yang sepele. Kata 'enteng' yang digunakan pun memiliki konotasi yang negatif. Kata 'enteng' jika dibenturkan dengan konteks aduan, maka memiliki makna bahwa pihak UPI Bandung tidak memperdulikan nasib mahasiswa yang berharap besar pada dana beasiswa Bawaku. Redaksi yang dibangun dalam aduan nomor 40 ini memiliki kesan yang menuntut kepada Pihak UPI terkait beasiswa Bawaku.

Dari 47 aduan dan aspirasi yang terdapat dalam LAPOR UPI ditemukan 17 aduan dan aspirasi yang memenuhi indikator sangat tidak santun. Berikut adalah jumlah persentasenya.

$$
\begin{gathered}
\text { Sangat tidak santun }=\frac{4}{47} \times 100 \% \\
=8,5 \%
\end{gathered}
$$

Berdasarkan hasil perhitungan di atas, dapat diketahui bahwa ditemukan 4 data aduan dan aspirasi yang termasuk ke dalam kategori sangat tidak santun dengan persentase sebesar $8,5 \%$. Besaran persentase ini jauh lebih kecil dibandingkan dengan tingkat kesantunan yang lain. Hal ini menunjukkan bahwa pihak yang memberikan aduan dan aspirasi belum sampai pada kategori sangat tidak santun. Jumlah persentase yang kecil menjadi penanda baik, karena menunjukkan bahwa pihak yang memberikan aduan dan aspirasi masih menyampaikan dengan cara yang santun. Selain itu, 8,5\% ini menunjukkan bahwa tidak banyak aduan dan aspirasi yang disampaikan dengan diksi-diksi yang tidak sopan dan berkonotasi negatif.

\section{Pembahasan}

Setelah melihat besaran persentase di setiap tingkat kesantunan berbahasa, maka dapat diurutkan dari persentase terbesar sampai dengan persentase terkecil sebagai berikut.

Tabel 1. Persentase Tingkat Kesantunan Berbahasa Aduan dan Aspirasi dalam

\section{LAPOR UPI.}

\begin{tabular}{cll}
\hline No. & Kategori & Persentase \\
\cline { 1 - 2 } 1. & Santun & $36,2 \%$ \\
\cline { 1 - 2 } 2. & $\begin{array}{c}\text { Sangat } \\
\text { santun }\end{array}$ & $31,9 \%$ \\
\cline { 2 - 2 } 3. & Tidak santun & $23,4 \%$ \\
\cline { 2 - 2 } 4. & $\begin{array}{c}\text { Sangat tidak } \\
\text { santun }\end{array}$ & $8,5 \%$ \\
& Total & $100 \%$ \\
\hline
\end{tabular}

Berdasarkan tabel 1 di atas, dapat diketahui bahwa penelitian ini menemukan 15 data aduan dan aspirasi kategori sangat santun dengan persentase 32\%, 17 data aduan dan aspirasi kategori santun dengan persentase $36 \%$, 11 data aduan dan aspirasi kategori tidak santun dengan persentase $23 \%$, dan 4 data aduan dan aspirasi kategori sangat tidak santun dengan persentase hampir 9\%. Pihak yang memberikan aduan dan aspirasi baik itu mahasiswa, peserta PPG/PLPG, dan orang tua mahasiswa dominan menyampaikan aduan dan aspirasi dengan cara yang santun. Hasil penelitian ini sama dengan penelitian dari Yati dan Suprapti (2016) yang menyebutkan bahwa percakapan mahasiswa Jurusan Kimia angkatan 2012 tergolong santun. Selain itu, 
empat kategori tingkat kesantunan berbahasa penelitian ini sama dengan penelitian dari Zamzani, Musfiroh, Maslakhah, Listyorini, dan Yayuk (2011, pp. 42-43).

Kesantunan seseorang dalam menyampaikan aduan dan aspirasi tentu tidak akan pernah terlepas dari faktor-faktor internal ataupun eksternal yang mempengaruhi. Hal itu dikarenakan, seseorang harus mengetahui lawan tutur, tuturan, dan konteks (Bachari \& Juansah, 2017; Saifullah, 2018).

Dari 47 data aduan dan aspirasi, seluruh aduan dan aspirasi disampaikan kepada pihak-pihak yang memangku jabatan tinggi atau petinggi di UPI Bandung. Status sosial yang berbeda menjadi faktor terbesar yang mempengaruhi pihak yang memberikan aduan dan aspirasi untuk menyampaikan aduan dan aspirasinya dengan cara santun. Hal itu pun sejalan dengan pendapat dari Brown dan Levinson (1987) yang menyebutkan bahwa setidaknya ada tiga faktor sosial yang terlibat dalam memutuskan bagaimana bersikap sopan: (1) seseorang cenderung lebih sopan kepada atasan sosial; (2) seseorang cenderung lebih sopan kepada orang yang tidak dikenalnya; (3) dalam setiap budaya terdapat norma dan nilai yang mempengaruhi tingkat pengenaan atau ketidaksukaan suatu ucapan, dan seseorang cenderung lebih sopan untuk pengenaan yang lebih serius.

Sejalan dengan Brown dan Levinson, Ide (1982, p. 366) menyebutkan bahwa ada berbagai faktor sosial dan psikologis yang terlibat dalam aturan kesantunan. Faktorfaktor ini banyak dan saling terkait, tetapi yang utama adalah (1) posisi sosial, (2) kekuasaan, (3) usia, dan (4) formalitas. Berkenaan dengan faktor-faktor ini, kita dapat mengajukan tiga aturan dasar dan aturan utama kesantunan, yaitu (1) bersikap sopan kepada seseorang yang memiliki status sosial lebih tinggi; (2) bersikap sopan kepada orang yang berkuasa; (3) bersikap sopan kepada orang yang lebih tua. Selain itu, kita pun harus bersikap sopan ketika suasana formal. Yule (1996, p. 59) juga menyebutkan bahwa dalam praktik kesantunan kerap kali melibatkan status lawan tutur berdasarkan nilai-nilai sosial terkait dengan usia dan kekuasaan.

\section{SIMPULAN}

Berdasarkan hasil temuan dan analisis dapat disimpulkan bahwa aduan dan aspirasi yang disampaikan oleh mahasiswa, peserta PLPG/PPG, orang tua, dan pihak lainnya melalui LAPOR UPI disampaikan dengan cara santun. Jumlah persentase kategori sangat santun dan santun jauh lebih besar daripada kategori tidak santun dan sangat tidak santun. Hal itu dikarenakan pihak yang dituju dalam aduan dan aspirasi memiliki status sosial yang berbeda, sehingga terdorong untuk menyampaikan aduan dan aspirasi dengan cara yang santun.

\section{DAFTAR PUSTAKA}

Bachari, A. D., \& Juansah, D. E. (2017). Pragmatik: Analisis Penggunaan Bahasa (M. Fasya (ed.)). Bandung: Prodi Linguistik Sekolah Pascasarjana Universitas Pendidikan Indonesia.

Birner, B. J. (2013). Introduction to Pragmatics. UK: Willey-Blackwell.

Brown, P. (2015). Politeness and Language. International Encyclopedia of the Social \& Behavioral Sciences, 18, 326330.

Brown, P., \& Levinson, S. C. (1987). Politeness: Some Universals in Language Usage (J. J. Gumperz (ed.)). Cambridge: Cambridge University Press.

Cruse, A. (2006). A Glossary of Semantics and Pragmatics. Edinburgh: Edinburgh University Press Ltd.

Holmes, J. (2009). Politeness Strategies as Linguistic Variables. In J. L. Mey (Ed.), Concise Encyclopedia of Pragmatics (2nd ed., pp. 711-723). UK: Elsevier Ltd. 
Ide, S. (1982). Japanese sociolinguistics politeness and women's language. Lingua, 57, 357-385.

Kasper, G. (1990). Linguistic politeness: Current research issues. Journal of Pragmatics, 14, 193-218.

Leech, G. (2007). Politeness: Is there an East-West divide? Journal of Politeness Research, 3, 137-206.

Leech, G. (2014). The Pragmatics of Politeness. Oxford University Press. 1

Levinson, S. C. (1983). Pragmatics. Cambridge: Cambridge Univeristy Press.

Saifullah, A. R. (2018). Semantik dan Dinamika Pergulatan Makna (S. B. Hastuti (ed.)). Bandung: Bumi Aksara. Soyomukti, N. (2012). Pengantar Ilmu Komunikasi (M. Sandra (ed.)). Yogyakarta: Ar-Ruzz Media.

Sperber, D., \& Wilson, D. (1995). Relevance: Communication and cognition. Oxford UK dan Cambridge USA: Blackwell Publisher.

Thomas, J. (1995). Meaning in Interaction: an Introduction to Pragmatics. London: Routledge.

Verschueren, J. (1999). Understanding Pragmatics. Oxford: Oxford University Press.

Yati, A., \& Suprapti, P. (2016). Kajian Pragmatik Wujud Kesantunan Berbahasa Mahasiswa Jurusan Kimia Tahun 2012 Kepada Dosen Melalui Media Short Message Service. Risenologi KPM UNJ, 1(2), 91-101.

Yule, G. (1996). Pragmatics. Oxford: Oxford University Press.

Zamzani, Musfiroh, T., Maslakhah, S., Listyorini, A., \& R., Y. E. (2011). Pengembangan Alat Ukur Kesantunan Bahasa Indonesia dalam Interaksi Sosial Bersemuka. LITERA, 10(1), 3550 . 